\title{
The effect of age, sex and level of intake of dietary fibre from wheat on large-bowel function in thirty healthy subjects
}

\author{
BY ALISON M. STEPHEN ${ }^{1}$, H. S. WIGGINS ${ }^{1}$, H. N. ENGLYST ${ }^{1}$, \\ T. J. COLE ${ }^{2}$, B. J. WA YMAN ${ }^{3}$ AND J. H. CUMMINGS ${ }^{1 *}$ \\ ${ }^{1} M R C$ Dunn Clinical Nutrition Centre, 100 Tennis Court Road, Cambridge CB2 1QL, \\ ${ }^{2}$ Dunn Nutritional Laboratory, Milton Road, Cambridge CB4 IXJ, ${ }^{3}$ Dalgety-Spillers \\ Research and Technology Centre, Bury Road, Kennett, Newmarket, Suffolk
}

(Received 16 July 1985 - Accepted 15 April 1986)

\begin{abstract}
1. To evaluate the effect of age, sex and level of intake on the colonic response to wheat fibre, thirty healthy volunteers aged 17-62 years (nineteen men, eleven women) recruited from a local industry, were divided into four groups and given a controlled diet for two 3-week periods. The diet contained white bread during one period or one of four different amounts of bran-enriched wholemeal bread during the other $(30,60,110,170 \mathrm{~g} / \mathrm{d})$.

2. Wide variation was observed between subjects in stool weight on the basal diet and in response to wheat fibre. Stepwise regression analysis showed that the variation in stool weight was significantly related to sex $(t 4 \cdot 0$, $P<0.001$ ) but not to age, height, weight or energy:fibre intakes on the basal diet. Stool weight in men $(162$ (SE 11$) \mathrm{g} / \mathrm{d}$ ) was approximately double that in women $(83(\mathrm{SE} 11) \mathrm{g} / \mathrm{d})$. Transit time and stool weight were closely related and the effect of sex on stool weight could be explained entirely by differences in transit.

3. The increase in stool weight with fibre was significantly related to dose $(t 4.18, P<0.001)$ with approximately $1 \mathrm{~g}$ non-starch polysaccharides (the main component of dietary fibre) increasing stool weight by $5 \mathrm{~g} / \mathrm{d}$. Smaller increases in stool weight were seen in females, persons with initially low stool weights and small people.

4. Faecal carbohydrate excretion increased with the addition of bran mainly due to increased amounts of cellulose and pentose (arabinose + xylose), whilst digestibjlity of dietary non-starch polysaccharide fell from 77.6 (SE 2.3$) \%$ on the white bread diet to 65.6 (SE 2.4$) \%$ with the added bran $(t 7.4, P<0.01, n 26)$.

5. Faecal pH was more acid in men than in women and was related to methane production. Methane producers had higher faecal $\mathrm{pH}$ than non-producers $(7.06$ (SE 0.11) v. $6.65(\mathrm{SE} \mathrm{0.1))}$, lower stool weight (g/d; 93 (SE 12) v. 156 (SE 13)) and slower transit times (h; 84.6 (SE 11.7) v. 48.6 (SE 6.6)).

6. These studies show that, when on similar diets, women have much lower stool weights and slower transit times than men. Furthermore, within the range of amounts of wheat fibre used in this and other published work, stool weight increases in linear proportion to the dose of fibre added to the diet. Methane excretion in breath is associated in this group of subjects with slow transit time and high faecal $\mathrm{pH}$.
\end{abstract}

It has been shown in a number of studies that dietary fibre, particularly that from cereals, affects large-bowel function (Royal College of Physicians, 1980). It is apparent from these studies that individuals respond in very different ways to identical dietary changes (Cummings et al. 1978a). This response may be governed by various factors such as the subject's age, sex, colonic anatomy and microbial content or life-style, such as the amount of exercise taken, exposure to stress, etc. Moreover, it is usually assumed that the colonic response to dietary fibre is related to the amount given, although this has never been shown in man. Since bowel function may be related to disease susceptibility it is important to know how it is determined.

In an attempt to relate the amount of fibre to the colonic response, and its modification by age, sex, height or weight, we have taken a group of thirty healthy volunteers of both sexes and from various social backgrounds, age 17-62 years, working in a local industry, and, under controlled dietary conditions, given them four different intakes of wheat fibre in the form of bran-enriched wholemeal bread. 
Table 1. Details of subjects and intakes of energy and fibre

(Values are means with $1 \mathrm{sE}$ )

\begin{tabular}{|c|c|c|c|c|c|c|c|c|}
\hline \multirow[t]{2}{*}{$\begin{array}{c}\text { Amount of bran enriched } \\
\text { bread }(\mathrm{g} / \mathrm{d}) . . . \\
\text { No. of subjects: } \\
\text { Men... } \\
\text { Women... }\end{array}$} & \multicolumn{2}{|c|}{$\begin{array}{r}30 \\
7 \\
3 \\
4\end{array}$} & & & & & & \\
\hline & Mean & SE & Mean & $\mathrm{SE}$ & Mean & $\mathbf{S E}$ & Mean & SE \\
\hline $\begin{array}{l}\text { Age (years) } \\
\text { Height }(\mathrm{m}) \\
\text { Wt (kg) } \\
\text { Percentage body fat }\end{array}$ & $\begin{array}{c}36 \cdot 3 \\
1 \cdot 64 \\
59 \cdot 2 \\
24 \cdot 6\end{array}$ & $\begin{array}{l}5 \cdot 6 \\
0.02 \\
2 \cdot 7 \\
2 \cdot 9\end{array}$ & $\begin{array}{c}35 \cdot 6 \\
1.68 \\
67 \cdot 5 \\
27 \cdot 4\end{array}$ & $\begin{array}{l}4 \cdot 7 \\
0 \cdot 03 \\
4 \cdot 0 \\
4 \cdot 1\end{array}$ & $\begin{array}{l}35 \cdot 9 \\
1 \cdot 71 \\
74 \cdot 4 \\
26 \cdot 3\end{array}$ & $\begin{array}{l}4 \cdot 8 \\
0 \cdot 05 \\
4 \cdot 3 \\
2 \cdot 7\end{array}$ & $\begin{array}{l}41 \cdot 1 \\
1 \cdot 74 \\
81 \cdot 5 \\
26 \cdot 0\end{array}$ & $\begin{array}{l}4 \cdot 3 \\
0 \cdot 02 \\
4 \cdot 0 \\
2 \cdot 6\end{array}$ \\
\hline $\begin{array}{l}\text { Energy intake }(\mathrm{MJ} / \mathrm{d}) \\
\text { Fibre intake* }(\mathrm{g} / \mathrm{d})\end{array}$ & $\begin{array}{l}10 \cdot 5 \\
16 \cdot 2\end{array}$ & $\begin{array}{l}1 \cdot 1 \\
0 \cdot 7\end{array}$ & $\begin{array}{l}11 \cdot 7 \\
16 \cdot 5\end{array}$ & $\begin{array}{l}1 \cdot 2 \\
0 \cdot 6\end{array}$ & $\begin{array}{l}11 \cdot 4 \\
17 \cdot 3\end{array}$ & $\begin{array}{l}1 \cdot 3 \\
1 \cdot 0\end{array}$ & $\begin{array}{l}14 \cdot 7 \\
18 \cdot 9\end{array}$ & $\begin{array}{l}0.5 \\
0.4\end{array}$ \\
\hline
\end{tabular}

* Fibre intakes measured as described on p. 354.

\section{METHODS \\ Subjects}

Thirty subjects, nineteen men and eleven women, were recruited from the staff of Dalgety-Spillers Research and Technology Centre in Cambridge and Kennett. The firm provides the research back-up for a world-wide company marketing human and animal foods and, at the time of the study (January-March 1978), had a total of 293 employees at these two sites. The subjects included both skilled and unskilled workers, scientific staff and management. All were interviewed before the start of the study and underwent medical examination including a check of blood lipids and haemoglobin. Height and weight were measured and percentage body fat calculated from measurements of skinfold thickness at four sites: biceps, triceps, subscapular and suprailiac (Durnin \& Womersley, 1974).

The subjects were then allocated to four groups each of which was to receive a different amount of bran-enriched bread. The highest-dose group contained only men because no women consumed sufficient bread in their basal diet to exchange for the top dose of bran-enriched bread (see p. 352). The other three groups were balanced for age and sex. Details of the subjects are shown in Table 1.

The energy intake of each subject during the study was based on his or her total energy requirement to maintain body-weight. This was calculated from their actual weight or, in the case of overweight subjects, their ideal body-weight-for-height, and was corrected for activity grade, age and sex as recommended by the World Health Organization (1973).

\section{Study plan}

The study took place over six consecutive weeks during which time the subjects pursued their normal activities but ate a controlled diet, prepared in the kitchens of Dalgety-Spillers. Everyone participating in the study met together to eat the mid-day meal while the rest of the day's foods (breakfast, evening meal and snacks) were packed into containers and taken home in the evenings. The importance of eating all the food was impressed on the subjects as was the need to refrain from eating any food not on the menu. Alcohol was not allowed. For 3 weeks they ate white bread as part of their diet and for a further 3-week period all or part of the white bread was substituted with bran-enriched wholemeal bread. No other dietary changes were made and the order in which the two breads were eaten was randomized. 
Table 2. Details of basal diet offered to subjects $(\mathrm{g} / \mathrm{d})$

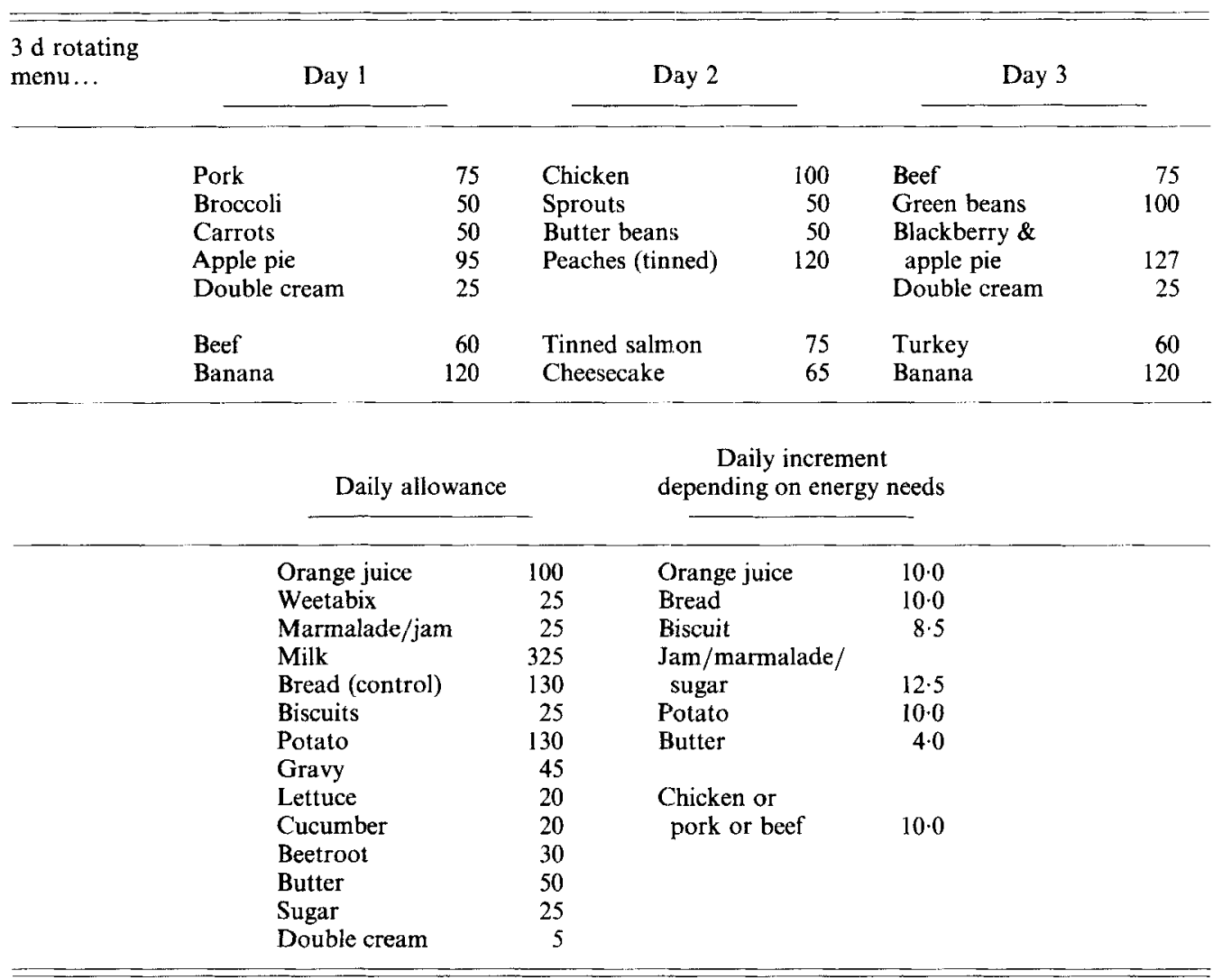

\section{Diets}

The basal diet for all the subjects consisted of three 1-d menus of similar composition which were fed in rotation throughout the study. Calculated energy requirements of the subjects differed widely, ranging from 7.8 to 18.5 (mean 9.7 ) $\mathrm{MJ} / \mathrm{d}$ but, to simplify arrangements in the diet kitchen, each subject was allocated to one of six energy-intake levels: $8 \cdot 0,9 \cdot 4$, $12 \cdot 2,14 \cdot 3,16 \cdot 4$ and $17.8 \mathrm{MJ} / \mathrm{d}$. In order to give the required energy intake, the basal diet was modified by incrementally adjusting the intake of seven foods (Table 2). Each subject was weighed weekly. At the end of week 1 final adjustments to their diet were made on the basis of weight changes and on their general feelings of the adequacy of the food they were receiving.

The composition of the basal diet, calculated from food tables (Paul \& Southgate, 1978) was $(/ \mathrm{d}$; one increment in parentheses): energy $9.40(0.70) \mathrm{MJ}$, fat $101.3(6.8) \mathrm{g}$, protein $75.9(4.4) \mathrm{g}$, carbohydrate $266.5(23.1) \mathrm{g}$, calcium $716(0.22) \mathrm{mg}$, cholesterol $286(16) \mathrm{mg}$. Dietary fibre, defined for the purpose of the present paper as the non-starch polysaccharides (NSP; measured as described on p. 354) was $15.4 \mathrm{~g} /$ basal diet $(3.6 \mathrm{~g}$ cellulose and $11.8 \mathrm{~g}$ non-cellulosic polysaccharide) and $0.45 \mathrm{~g}$ in the increment. The contribution to daily energy intake from fat was $40 \%$, protein $14 \%$ and carbohydrate $46 \%$. Salt, pepper, tea and coffee were allowed and a record kept of the amount of each used. Subjects were expected to keep their intake of these items constant from week to week. Average energy and fibre intakes whilst on the basal diet for each group are shown in Table 1. 
Table 3. Composition of bread (/kg dry matter) offered to subjects

\begin{tabular}{|c|c|c|}
\hline & Control & Bran-enriched \\
\hline Total energy $(\mathrm{kJ})$ & 17700 & 18300 \\
\hline Starch and dextrins* $(g)$ & 657 & 418 \\
\hline Resistant starch $\dagger(g)$ & 5 & 3 \\
\hline \multicolumn{3}{|l|}{ Free sugars $(g)$ : } \\
\hline Fructose & 11 & 17 \\
\hline Glucose & 4 & 8 \\
\hline Maltose & 56 & 49 \\
\hline Protein $\$$ (g) & 180 & 202 \\
\hline Fatty acids (g) & 25 & 36 \\
\hline Total non-starch polysaccharides (g) & 29 & 153 \\
\hline Cellulose $(\mathrm{g})$ & 3 & 33 \\
\hline Non-cellulosic polysaccharides (g) & 26 & 119 \\
\hline Hexose $(\mathrm{g})$ & 6 & 17 \\
\hline Pentose (g) & 19 & 98 \\
\hline Uronic acid (g) & 0 & 5 \\
\hline 'Lignin' (g) & 5 & 20 \\
\hline $\operatorname{Ash}(\mathrm{g})$ & 47 & 61 \\
\hline Calcium (mmol) & $62 \cdot 9$ & $33 \cdot 1$ \\
\hline Magnesium (mmol) & $17 \cdot 1$ & $92 \cdot 6$ \\
\hline Sodium (mmol) & 461 & 431 \\
\hline Potassium (mmol) & $61 \cdot 6$ & $168 \cdot 0$ \\
\hline Zinc $(\mu \mathrm{mol})$ & 157 & 577 \\
\hline Iron $(\mu \mathrm{mol})$ & 620 & 1320 \\
\hline Copper ( $\mu \mathrm{mol})$ & 58 & $95 \cdot 2$ \\
\hline Solids ( $\%$ of original loaves) & 636 & 590 \\
\hline
\end{tabular}

* As polymer.

† Starch made resistant to $\alpha$-amylase by baking. For details of methods, see p. 354 .

$\$$ Control, nitrogen $\times 5 \cdot 7$; bran-enriched $\mathrm{N} \times 5.83$.

The breads for the study were baked in a large batch beforehand and stored at $-20^{\circ}$ until needed. The white loaf consisted of white ( $72 \%$ extraction) flour, yeast, salt, gluten, malt, treacle, water and an improver. The recipe for the bran-enriched loaf was the same except that the flour was wholemedi and one-quarter was substituted with fine bran. A standard sieving test on the bran showed it to have the following relative particle size: $(\%)$ $>500 \mu \mathrm{m} \mathrm{40} \cdot 1,250-500 \mu \mathrm{m} \mathrm{38} \cdot 1,<250 \mu \mathrm{m} \mathrm{21 \cdot 7}$. The composition of the two breads is given in Table 3 .

Each of the four groups of subjects received a different amount of bran-enriched bread, either $30,60,110$ or $170 \mathrm{~g} / \mathrm{d}$, substituted in the diet for an equal amount of white bread. This gave a difference in intake of NSP between the two diets of $2 \cdot 2,4 \cdot 3,8 \cdot 0$ and $12 \cdot 3 \mathrm{~g} / \mathrm{d}$ respectively.

Because there was only $130 \mathrm{~g}$ bread/d in the basal diet and the highest dose of high-fibre bread was $170 \mathrm{~g} / \mathrm{d}$, only subjects who were eating at least +4 increments of diet could be included in the highest-dose group. This meant that the group who consumed $170 \mathrm{~g}$ high-fibre bread/d consisted entirely of men who had a correspondingly higher mean energy intake than the other groups (Table 1).

Duplicate samples of the breads and all the diets were taken for analysis.

Faecal markers and blood collections

Throughout the study the subjects took ten radio-opaque pellets with each meal $(30 / \mathrm{d})$ as balance markers as described by Branch \& Cummings (1978). During the third week of 
each diet-period mean transit time (MTT) through the gut was measured by giving three doses of twenty radio-opaque pellets of different types with breakfast on three successive days (Cummings et al. 1976 b). Faeces were collected from day 13 to day 21 of each diet-period, each stool being collected separately in a plastic bag, suspended over a toilet, which was then tied, labelled and put into solid carbon dioxide to freeze. The subjects were given containers of solid $\mathrm{CO}_{2}$ to take home each day, and similar facilities were available at their place of work in selected toilets. The faeces passed on days 14-21 (the final week) of each diet-period were pooled, freeze-dried, ground in an automatic agate mortar (Glen Creston Ltd), mixed and portions taken for analyses of fat, nitrogen, energy, carbohydrate and minerals. Faecal pH was measured in freshly-passed stools using an EIL soil electrode during the final $7 \mathrm{~d}$ of each diet-period. At least three readings were taken in each stool and an average of $2 \cdot 3$ stools/diet-period per subject were examined.

Breath methane was measured in end-expiratory air collected during lunch-time from each subject during the control-diet period. Methane was determined by gas-liquid chromatography using a Pye 104 gas-liquid chromatograph (Pye Instruments, Cambridge) fitted with a $2 \mathrm{ml}$ gas sampling loop and a flame-ionization detector. Methane was separated on a $2 \mathrm{~m} \times 4 \mathrm{~mm}$ glass column packed with Poropak-Q at $50^{\circ}$ using $\mathrm{N}_{2}$ as the carrier gas. The instrument was calibrated with a $50 \mu \mathrm{l} / 1$ standard gas (British Oxygen Co. Special Gases). Room-air methane was measured simultaneously and the value subtracted from that obtained in expired air.

Fasting blood samples for haemoglobin, lipids and minerals were taken from each subject at the start of the study and at the end of each diet-period.

\section{Chemical methods}

Dietary and faecal fatty acids were determined by the method outlined by Wootton (1974). Total $\mathrm{N}$ measurements were carried out using a Tecator Kjeldahl apparatus (Tecator Ltd, Bristol) and gross energy using an Adiabatic Bomb Calorimeter (Gallenkamp). Benzoic acid, thermochemical grade, was the reference source for calibration of the instrument. All determinations were done on duplicate samples. Blood haemoglobin was measured by the cyanmethemoglobin method of Van Kampen \& Zijlstra (1961) using a commercial kit (Boehringer Mannheim, catalogue no. 124729). Total and high-density lipoprotein (HDL) cholesterol were measured by the cholesterol esterase ( $E C$ 3.1.1.13)-cholesterol oxidase (EC 1.1.3.6) method of Roschlau et al. (1974) using a commercial kit (Boehringer Mannheim, catalogue no. 124087), and total triglycerides enzymically by the method of Wahlefeld (1974) (Boehringer Mannheim, catalogue no. 150606).

The procedure for the separation of the HDL fraction from plasma was essentially that of Burstein et al. (1970). The very-low-density lipoprotein (VLDL) and low-density lipoprotein (LDL) fractions were precipitated from $2 \mathrm{ml}$ blood plasma by the addition of $80 \mu \mathrm{l}$ heparin solution $(5000 \mathrm{units} / \mathrm{ml}$ ) and $200 \mu \mathrm{l} 1 \mathrm{M}$-manganese chloride. The mixture was held in an ice-bath for $30 \mathrm{~min}$ and then centrifuged at $3000 \mathrm{~g}$ for $30 \mathrm{~min}$ at $4^{\circ}$. The supernatant fraction contained the HDL. Before determining cholesterol on the separated HDL fraction, $20 \mu$ lof a solution of EDTA $(0.4 \mathrm{M}, \mathrm{pH} 7 \cdot 7)$ was added to $1 \mathrm{ml}$ supernatant fraction to prevent any inhibition of the enzyme in the assay for cholesterol by excess manganese (Professor B. Lewis, St Thomas' Hospital Medical School, private communication).

Faecal carbohydrates. Total carbohydrate in faeces was measured by gas-liquid chromatography of alditol acetates of individual sugars after hydrolysis with $1 \mathrm{M}$-sulphuric acid to solubilize noncellulosic sugars and $12 \mathrm{M}_{-} \mathrm{H}_{2} \mathrm{SO}_{4}$ for cellulose.

Approximately $200 \mathrm{mg}$ faecal powder were weighed accurately into a screw-capped tube and $10 \mathrm{ml} 1 \mathrm{M}-\mathrm{H}_{2} \mathrm{SO}_{4}$ added. The mixture was heated for $2.5 \mathrm{~h}$ in a boiling water-bath. 
After cooling, $5 \mathrm{mg}$ inositol and $2 \mathrm{mg}$ erythrytol were added as internal standards and the solution filtered through a Whatman G4 glass-fibre filter disc supported in a sintered-glass Gooch crucible.

Non-cellulosic sugars. The filtrate was neutralized by adding an excess of finely-powdered calcium carbonate and stirring overnight. After filtering again the neutralized solution was loaded onto a mixed-bed ion-exchange resin which had been treated with saturated ammonium carbonate and washed through with $150 \mathrm{ml}$ water. The eluate was taken to dryness in a rotary evaporator at $50^{\circ}$ and the residues transferred to tubes with deionized water. The contents of the tubes were dried on a Buchler evapomix and the residue dissolved in a solution of sodium borohydride $(10 \mathrm{mg} / \mathrm{ml})$ in $0.3 \mathrm{M}$-ammonium hydroxide. After at least $1 \mathrm{~h}, 3 \mathrm{ml}$ methanol and $1 \mathrm{ml} 1 \mathrm{M}$-acetic acid were added to the tube to destroy unreacted borohydride. The mixture was again taken to dryness on the evapomix, $3 \mathrm{ml}$ methanol added and again taken to dryness. This was repeated twice more. After the final drying, $1 \mathrm{ml}$ acetic anhydride was added and the mixture heated for $2 \mathrm{~h}$ at $120^{\circ}$. For the first $15 \mathrm{~min}$ the tubes were shaken at frequent intervals to ensure suspension of the solids.

The alditol acetates formed by this procedure were measured by gas-liquid chromatography using a Pye 204 gas-liquid chromatograph as previously reported (Englyst et al. 1982).

Cellulose. The filtered residue obtained from the initial $1 \mathrm{M}$-sulphuric acid hydrolysis was washed well with water and with acetone and allowed to air-dry completely. The crucible containing the filter disc and its residue was placed in a small beaker and the contents mixed with $12 \mathrm{M}^{-} \mathrm{H}_{2} \mathrm{SO}_{4}$ at $40^{\circ}$ using a fine glass rod. The beakers were then allowed to stand for $24-48 \mathrm{~h}$ at $4^{\circ}$. The crucibles were removed from the beakers with forceps and the acid from the sides of the crucible washed into the beaker with a minimum of water. The crucible was then placed in an adaptor, filtered under pressure and the contents washed several times with small quantities of water. All these washings and the contents of the beaker were combined and made up to $100 \mathrm{ml}$ in a volumetric flask. The hexose content of this solution was determined using the anthrone reaction (Roe, 1955). Cellulose is reported as hexose.

Food carbohydrate. NSP and resistant starch in the breads and diets were measured by the method of Englyst et al. (1982) (Table 3). Starch was gelatinized, incubated with amyloglucosidase (glucan 1, 4- $\alpha$-glucosidase, EC 3.2.1.3) and measured as glucose and then converted to give a value for starch as polymer. Free sugars were extracted with buffer at pH 5.2 and measured as trimethyl silyl oximes (Brobst \& Lott, 1966; Brittain et al. 1971).

Lignin. Lignin was measured by the method of Southgate (1976).

Minerals. Ca, magnesium, zinc, iron, sodium, potassium and copper were determined in blood at the Laboratory of the Government Chemist using plasma emission spectrophotometry.

\section{Statistics}

All results are given as the means with their standard errors. Statistical analysis is by multiple stepwise regression analysis on $\log _{\mathrm{e}}$ transformed data.

\section{RESULTS}

\section{Stool weight and transit time}

Average daily stool weight for the whole group of subjects on the control diet was 130 (SE 11) g/d and MTT was 61 (SE 6.6) h. However, as may be seen from Fig. 1, there was a greater than fivefold range in stool weight $(48-285 \mathrm{~g} / \mathrm{d})$ and an even greater range in MTT $(22-148 \mathrm{~h})$. MTT and stool weight were significantly inversely correlated $(r-0 \cdot 80 ; n 29)$. Stool weight $(\mathrm{g} / \mathrm{d})$ in the men was approximately double that of the women (men 162 (SE 11), women 83 (SE 11); $t 4.0, P<0.001$ ) and similarly transit time (h) was 

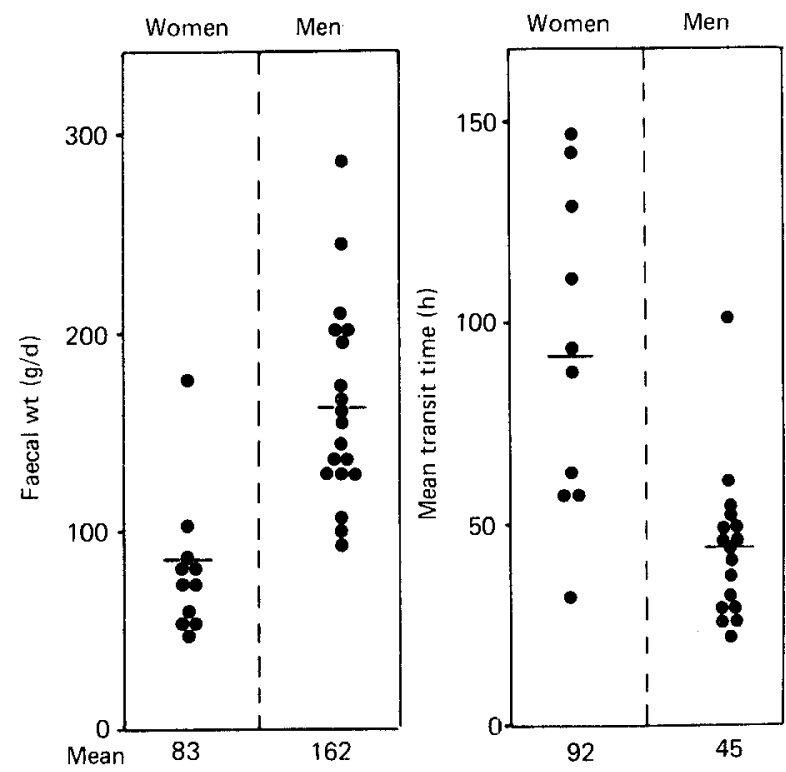

Fig. 1. Average daily faecal weight $(\mathrm{g} / \mathrm{d})$ and mean transit time $(\mathrm{h})$ during the final $7 \mathrm{~d}$ of the basal (white bread)-diet period. Means are arithmetic means.

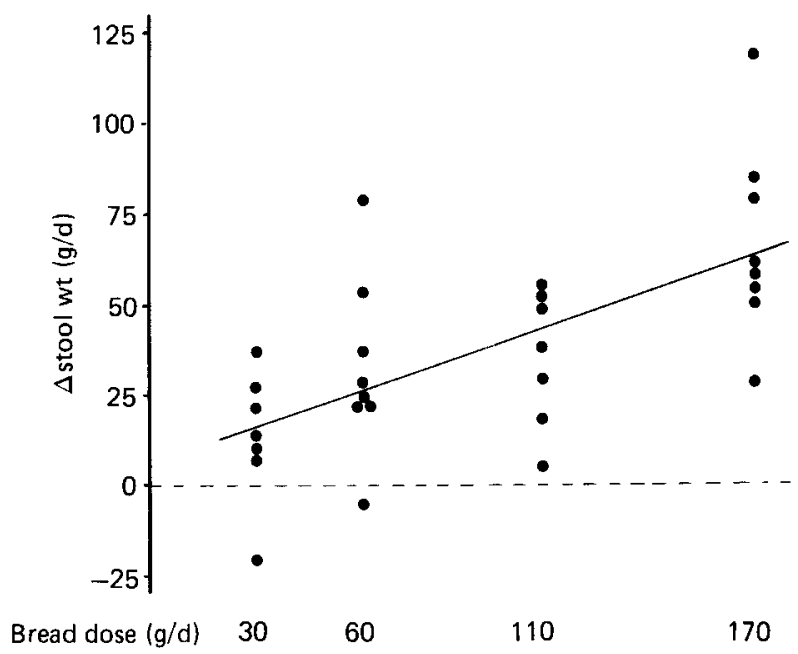

Fig. 2. Change $(\triangle)$ in faecal weight due to bran-enriched bread (average daily stool weight during test period minus average during control period: $\mathrm{g} / \mathrm{d}$ ). Regression equation: $y=0 \cdot 34 x+5 \cdot 92, n 30, r 0 \cdot 64$.

significantly different between the two groups (men 44.8 (SE 4.3), women 91.7 (SE 12.8); $t 4.29, P<0.001$ ). Using stepwise regression analysis, stool weight on the basal diet was significantly related to sex $(t 4 \cdot 0, P<0 \cdot 001)$ but not to age, height, weight or energy:fibre intake. MTT and stool weight were closely related, however, and if the effect of sex on stool weight was adjusted for transit time it was no longer significant.

Table 4 gives the average stool weights and transit times at each of the four levels of bread intake and Fig. 2 the values for individuals. Twenty-eight of the thirty subjects showed an 
Table 4. Effect of bran-enriched bread on daily transit time, faecal output and composition (Mean values with their standard errors)

\begin{tabular}{|c|c|c|c|c|c|c|c|c|}
\hline \multirow{3}{*}{$\begin{array}{l}\text { Amount of bran-enriched } \\
\text { bread }(g / d) \ldots \\
\text { Dietary period... }\end{array}$} & \multicolumn{4}{|c|}{30} & \multicolumn{4}{|c|}{60} \\
\hline & \multicolumn{2}{|c|}{$\mathrm{C}$} & \multicolumn{2}{|c|}{$+B$} & \multicolumn{2}{|c|}{$\mathrm{C}$} & \multicolumn{2}{|c|}{$+B$} \\
\hline & Mean & $\mathbf{S E}$ & Mean & $\mathbf{S E}$ & Mean & SE & Mean & SE \\
\hline Faecal weight (g) & 114 & 20 & $128^{* *}$ & 22 & 130 & 28 & $163^{* * *}$ & 27 \\
\hline Transit time (h) & 66 & 17 & 53 & 12 & 68 & 14 & $54^{*}$ & 10 \\
\hline Faecal solids (g) & 28 & 3 & $30^{*}$ & 2 & 29 & 3 & $36^{* *}$ & 3 \\
\hline Energy $(\mathrm{kJ})$ & 524 & 52 & $571^{*}$ & 49 & 565 & 60 & $679^{* *}$ & 60 \\
\hline Fat (g) & $2 \cdot 3$ & 0.3 & $2 \cdot 4$ & 0.3 & $2 \cdot 8$ & 0.3 & $2 \cdot 9$ & 0.5 \\
\hline Nitrogen (g) & $1 \cdot 5$ & $0 \cdot 2$ & 1.6 & 0.2 & $1 \cdot 5$ & 0.2 & $1 \cdot 7^{*}$ & $0 \cdot 2$ \\
\hline \multirow{3}{*}{$\begin{array}{l}\text { Amount of bran-enriched } \\
\text { bread }(g / d) \ldots \\
\text { Dietary period... }\end{array}$} & \multicolumn{4}{|c|}{110} & \multicolumn{4}{|c|}{170} \\
\hline & \multicolumn{2}{|c|}{$\mathrm{C}$} & \multicolumn{2}{|c|}{$+B$} & \multicolumn{2}{|c|}{$\mathrm{C}$} & \multicolumn{2}{|c|}{$+B$} \\
\hline & Mean & $\mathbf{S E}$ & Mean & $\mathbf{S E}$ & Mean & SE & Mean & SE \\
\hline Faecal weight (g) & 110 & 15 & $145^{* * *}$ & 13 & 173 & 15 & $240^{* * *}$ & 14 \\
\hline Transit time $(\mathrm{h})$ & 73 & 15 & 59 & 7 & 39 & 4 & 34 & 3 \\
\hline Faecal solids (g) & 28 & 3 & $36^{* * *}$ & 2 & 37 & 2 & $54^{* * *}$ & 2 \\
\hline Energy $(\mathbf{k J})$ & 557 & 76 & $684^{* *}$ & 58 & 747 & 39 & $1101^{* * *}$ & 37 \\
\hline Fat $(\mathrm{g})$ & 3.5 & 0.7 & 3.7 & 0.8 & $4 \cdot 3$ & $0 \cdot 3$ & $4 \cdot 7$ & 0.3 \\
\hline Nitrogen (g) & $1 \cdot 5$ & 0.2 & $1 \cdot 6$ & $0 \cdot 2$ & $2 \cdot 1$ & $0 \cdot 1$ & $2 \cdot 4^{* *}$ & $0 \cdot 1$ \\
\hline
\end{tabular}

C, control; + B, bran-enriched bread.

Mean values were significantly different from control values: ${ }^{*} P<0.05,{ }^{* *} P<0.01,{ }^{* * *} P<0.001$.

increase in stool output with the bran-enriched bread. The increase in stool weight and the natural logs of the change (representing proportional rather than absolute differences) were analysed with respect to bread dose, sex, age, height, weight, energy intakes and for period effects. The increase in stool weight $(\mathrm{g} / \mathrm{d})$ on the high-fibre diet was significantly related to dose $(t 4.2, P<0.001)$ with a regression coefficient of 0.33 (SE 0.08). Approximately $3 \mathrm{~g}$ bread, therefore, led to an increase of $1 \mathrm{~g}$ in wet stool weight. Other covariates significantly related to the increase were sex (regression coefficient $b-42, t-2.9, P<0.01$ ), initial stool weight $(b-0.2, t-2.4, P<0.05)$ and height $(b-155, t-2.5, P<0.05)$. A smaller increase in stool weight with fibre was seen therefore in females, in persons with low initial stool weight and in small people.

Transit time (h) fell significantly from 61 (SE 6.6) to 50 (SE 4.4) when the high-fibre bread was added to the diet $(t-3 \cdot 12, P<0 \cdot 01)$. There was no significant dose effect even after adjusting for other covariates. One covariate to emerge as significant was period. The reduction in MTT was $20 \%$ less when fibre was given in the second period $(P<0.01)$.

\section{Faecal $p H$ and methane}

Faecal pH was 6.70 (SE $0.09 ; n$ 23) on the control diet (range $5.6-7 \cdot 8$ ) and was unchanged by the addition of bran $(6.79$ (SE 0.10$) ; t 1.8)$. $\mathrm{pH}$ was negatively related to stool weight $(r-0.85)$ and, after adjustment for this, was significantly higher in women (7.18 (SE 0.08), $n 11)$ than in men $(6.51$ (SE 0.07$), n 15 ; t 2.4)$. Transit time and $\mathrm{pH}$ were also related $(r 0.79$, $n$ 26).

There were eleven methane producers (breath methane greater than $1 \mu \mathrm{l} / 1$ above room 
Table 5. Effect of bran-enriched bread on faecal carbohydrate excretion $(\mathrm{g} / \mathrm{d})$

(Mean values with their standard errors)

\begin{tabular}{|c|c|c|c|c|c|c|c|c|}
\hline \multirow{3}{*}{$\begin{array}{l}\text { Amount of bran-enriched } \\
\text { bread }(\mathrm{g} / \mathrm{d}) \ldots \\
\text { Dietary period... }\end{array}$} & \multicolumn{4}{|c|}{30} & \multicolumn{4}{|c|}{60} \\
\hline & \multicolumn{2}{|c|}{$\mathrm{C}$} & \multicolumn{2}{|c|}{$+\mathbf{B}$} & \multicolumn{2}{|c|}{$\mathrm{C}$} & \multicolumn{2}{|c|}{$+\mathbf{B}$} \\
\hline & Mean & $\mathrm{SE}$ & Mean & SE & Mean & SE & Mean & SE \\
\hline Total carbohydrate & $4 \cdot 22$ & $1 \cdot 1$ & $4 \cdot 84$ & 0.7 & $3 \cdot 77$ & 0.9 & $7 \cdot 25^{* * *}$ & $1 \cdot 4$ \\
\hline Cellulose & 1.53 & 0.5 & 1.57 & $0 \cdot 3$ & $1 \cdot 23$ & 0.32 & $2 \cdot 21^{* * *}$ & 0.45 \\
\hline Arabinose + xylose & 1.07 & $0 \cdot 13$ & $1 \cdot 81^{* * *}$ & $0 \cdot 12$ & $1 \cdot 25$ & 0.19 & $3 \cdot 22 * * *$ & 0.37 \\
\hline NCP-glucose & 0.95 & 0.4 & $0 \cdot 80$ & $0 \cdot 3$ & $1 \cdot 07$ & 0.4 & 1.45 & \multirow[t]{2}{*}{0.5} \\
\hline$n \dagger$ & \multicolumn{2}{|c|}{6} & & & \multicolumn{2}{|c|}{8} & & \\
\hline \multirow{3}{*}{$\begin{array}{l}\text { Amount of bran-enriched } \\
\text { bread }(\mathrm{g} / \mathrm{d}) \ldots \\
\text { Dietary period... }\end{array}$} & \multicolumn{4}{|c|}{110} & \multicolumn{4}{|c|}{170} \\
\hline & \multicolumn{2}{|c|}{ C } & \multicolumn{2}{|c|}{$+B$} & \multicolumn{2}{|c|}{ C } & \multicolumn{2}{|c|}{$+B$} \\
\hline & Mean & $\mathrm{SE}$ & Mean & $\mathrm{SE}$ & Mean & SE & Mean & $\mathrm{SE}$ \\
\hline Total carbohydrate & $3 \cdot 18$ & 0.4 & $7 \cdot 61 * * *$ & 0.4 & $4 \cdot 15$ & 0.5 & $12 \cdot 3^{* * *}$ & 0 \\
\hline Cellulose & 0.92 & $0 \cdot 1$ & $2 \cdot 39 * * *$ & $0 \cdot 1$ & $1 \cdot 27$ & $0 \cdot 1$ & $3 \cdot 73^{* * *}$ & 0 \\
\hline Arabinose + xylose & $1 \cdot 06$ & $0 \cdot 1$ & $3 \cdot 96 * * *$ & 0.2 & 1.07 & 0.1 & $6 \cdot 15^{* * *}$ & 0 \\
\hline NCP-glucose & 0.57 & 0.2 & 0.52 & 0.1 & 1.01 & 0.2 & $1 \cdot 38$ & 0 \\
\hline$n \dagger$ & & 7 & & & & & & \\
\hline
\end{tabular}

C, control; + B, bran-enriched bread; NCP-glucose, non-cellulosic polysaccharide glucose.

Mean values were significantly different from control values: $* P<0.05, * * P<0.01, * * * P<0.001$.

$\dagger$ No. of subjects for which analysis was completed.

air) who had an average end-expiratory breath methane of $35 \cdot 4$ (SE 6.1) $\mu 1 / 1$. Breath methane was highly significantly correlated with transit time $(t \cdot 4 \cdot 1)$ and also with faecal $\mathrm{pH}$. MTT (h) was longer in producers $(84.6$ (SE 11.7) v. 48.6 (SE 6.6)) and producers had higher $\mathrm{pH}$ (producers 7.06 (SE 0.11) $v$. non-producers 6.65 (SE 0.10$) ; t 2.47, P<0.025$ ) and had lower stool weight (g/d; producers 93 (SE 12) v. non-producers 156 (SE 13), $t 3 \cdot 23$, $P<0.005$ ).

\section{Faecal composition}

Energy, fat and $N$ (Table 4). Faecal N, carbohydrate and energy were all highly significantly related to stool weight $(P<0.001)$. After adjusting for stool weight, $\mathrm{N}$ was significantly related to energy intake $(t 4 \cdot 9)$ as was faecal fat $(t 8 \cdot 6)$. On changing the diet neither faecal $\mathrm{N}$ nor fat was related to the dose of bran. Faecal energy, however, showed a strong dose response $(P<0.001)$.

Carbohydrate (Table 5). With the addition of bran-enriched bread to the diet, total faecal carbohydrate excretion increased in twenty-four of twenty-six subjects on whom detailed faecal carbohydrate analysis was done. The increase was largely accounted for by cellulose and pentose sugars (arabinose + xylose). Only 25\% of the NSP present in the basal diet could be recovered in the stools but $73 \%$ of the NSP added in the bran-enriched bread survived digestion in the gut.

\section{Body-weight, blood lipids and minerals}

Body-weight (kg) for the whole group fell slightly during the study from 70.9 (SE 2.4) (start) to 69.9 (SE 2.4) (finish). The change occurred mainly in the first week of the study. It was independent of the type of bread being eaten. 


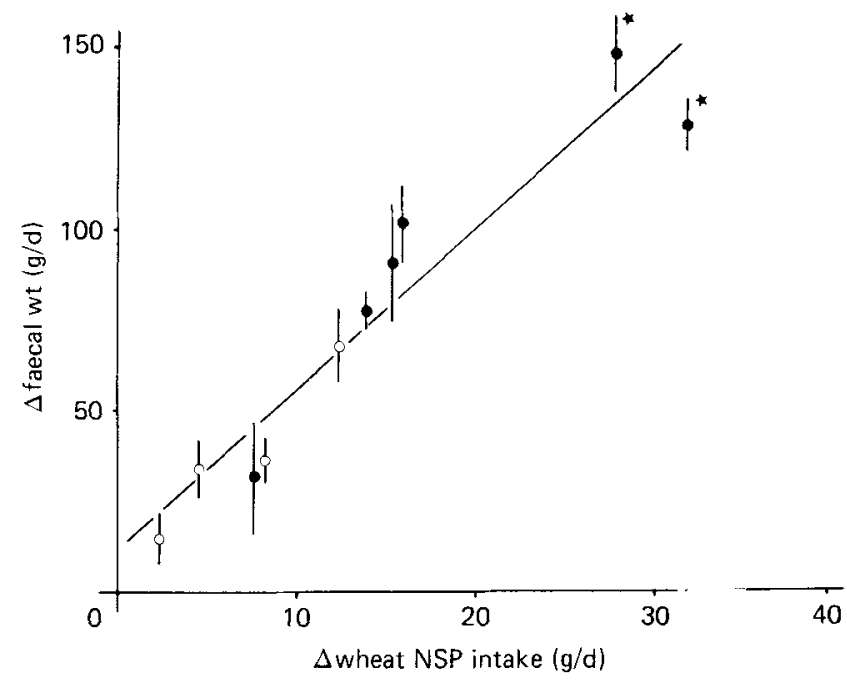

Fig. 3. Average changes $(\triangle)$ in faecal weight in ten groups of healthy volunteers with increases in non-starch polysaccharide (NSP) intake (g/d) from wheat. (O) Present study; (O) values from Southgate et al. (1976), Cummings et al. (1976a, 1978a, 1979), Andersson et al. (1983). * Includes 'lignin' intake. Regression equation: $y=4.45 x+10 \cdot 6, n 10, r 0.95$.

The change in diet had no effect on blood levels of cholesterol, HDL-cholesterol, triglyceride, haemoglobin, $\mathrm{Ca}, \mathrm{Fe}, \mathrm{Mg}$ or $\mathrm{Zn}$.

\section{DISCUSSION}

The present study shows clearly that the change in faecal output induced by wheat bran is significantly related to dose over the range of intake studied. The component of bran responsible for these changes cannot be identified from the present study but other work has indicated that cell-wall material, particularly the NSP, is probably important in this respect (Cummings et al. 1978 a; Eastwood et al. 1980; Stephen \& Cummings, 1980). The amount of NSP given to the subjects as bran-enriched bread ranged from 2.8 to $15.7 \mathrm{~g} / \mathrm{d}$ and represented, at the highest dose, an approximate doubling of total NSP intake and twice that present in the average UK diet (Bingham et al. 1985). It was also about as much as an average group of people could be expected to eat from one single dietary source. Other studies have been reported in which wheat bran from breakfast cereals, biscuits, raw bran and purified wheat-NSP were given to subjects under controlled conditions (Southgate $e t$ al. 1976; Cummings et al. 1976a, 1978a, 1979; Andersson et al. 1983). Fig. 3 shows an overall dose-response line for these studies together with the present one. It may be seen that the group average response to wheat bran presented in a variety of forms is linear over a wide range of intakes. In the present study stool weight increased by about $5 \mathrm{~g}$ for every $1 \mathrm{~g}$ wheat-NSP. The range of increase for the other studies is $4 \cdot 2-7 \cdot 6 \mathrm{~g}$ stool $/ \mathrm{g} \mathrm{NSP}$ fed.

A striking feature of the results is the great individual variability in bowel habit on the basal diet and in the response to bran (Fig. 2). The increase in stool weight was correlated not only with dose but also with sex, the women showing a smaller increase than the men. Stepwise regression analysis of other variables which might relate to this showed that only sex was significant, and that this association with the female sex could be explained by transit time since the relation with sex was no longer significant when adjusted for MTT. Although the basal diets of the men and the women were different, because of their varying 
energy needs, the men taking $4.6 \mathrm{MJ} / \mathrm{d}$ more than the women, these differences and the attendant amounts of extra fat, protein, fibre, etc. were not statistically related to the variation in bowel habit. In fact protein and fat have little effect if any on bowel habit (Cummings et al. 1978b, 1979) and a difference in fibre intake of less than $5 \mathrm{~g} / \mathrm{d}$ on the basal diet is insufficient to explain the large contrast in stool weight. There must, therefore, be non-dietary factors which control colonic function. The women had considerably longer transit times (h) on the basal diet than the men (women 91.7 (SE 12.8) v. men 44.8 (SE 4.3)). Transit time has been shown on several occasions to be closely related to stool output (Burkitt et al. 1972; Cummings, 1978), to determine the response to fibre (Cummings, 1982) and to influence microbial metabolism in the colon (Stephen, 1980). The difference in bowel habit observed in the present study between men and women is therefore a reflection of the importance of transit time in determining individual patterns of colonic function.

The smaller stool weight of women may in fact confer a disadvantage on them in respect of their risk of developing colonic disease. Wornen are more likely to become constipated than men (Connell et al. 1965; Royal College of General Practitioners, 1979) and to develop diverticular disease (Gear, 1979). They also have a greater risk than men of cancer of the proximal colon at all ages and of the distal colon up to the age of 50 years (McMichael \& Potter, 1980, 1982).

The effect of the change in bread on transit time was to shorten it on average for the whole group. Individual responses varied considerably but there was no evidence of a normalization effect as reported in other studies (Payler et al. 1975).

\section{Faecal composition}

The change to a bran-enriched bread produced an increase in faecal excretion of energy and $\mathrm{N}$, as reported in previous studies of bread (Macrae et al. 1942; McCance \& Walsham, 1948). The mechanism of this change was once believed to represent an effect of fibre on small-bowel digestion but is now thought to be through the stimultion of colonic microbial growth and increased excretion of microbial solids which wheat bran is known to effect (Stephen \& Cummings, 1979, 1980).

Polymers containing glucose, galactose, mannose, rhamnose, fucose, arabinose, xylose and ribose were present in all faecal samples. The majority of faecal carbohydrate $(55-75 \%)$ during the control period was cellulose + arabinose + xylose. With bran supplementation the percentage of these three components increased, reaching $74-87 \%$ in the group taking the largest supplement $(170 \mathrm{~g}$ bread/d). The digestibility of this increased intake of cellulose and pentose can be calculated, assuming the added bran does not alter the breakdown of NSP in the basal diet. Average digestibility of the added NSP was 33\% (range 0-62\%). Some of the differences between individuals in the extent of metabolism of the bran NSP can be attributed to transit time. However, even in the groups on the higher intakes the variability is only partly explained on this basis $\left(r^{2} 0 \cdot 30\right)$.

It was noted in the present study that some subjects had relatively large amounts (maximum $4 \cdot 1 \mathrm{~g} / \mathrm{d}$ ) of an insoluble glucan in faeces that was analysed as non-cellulosic polysaccharide. The majority of this faecal non-cellulosic glucose had the chemical properties of partially-degraded starch (H. S. Wiggins, unpublished observations). In those subjects in whom it made up more than $1 \%$ of the dry weight $(n 9)$ it was present at this level in both control and high-bran periods. The amount was not related to the NSP content of the diet nor to its energy content and therefore was unlikely to originate in either of the breads. In the control period, when the NSP content of the diet was relatively constant, the faecal non-cellulosic glucose output was related to the arabinose + xylose output $(r 0.86$, $P<0.01)$ and also to MTT $(r 0.57)$. During the bran periods it was related inversely to the proportion of bran metabolized $(r 0.83, P<0.01)$. It is probable that faecal non- 
cellulosic glucose is starch and originates in a food, such as potato or banana, which was constant for all subjects in both periods, and is degraded by bacterial systems associated with the breakdown of insoluble NSP.

Faecal $\mathrm{pH}$ was unchanged by the bran, an observation also noted by Walker et al. (1979) in studies of African schoolchildren. Faecal $\mathrm{pH}$ is largely determined by fermentation of carbohydrate by the anaerobic flora of the large intestine and it might have been expected that the addition of a significant amount of fermentable carbohydrate to the diet of these subjects would have lowered $\mathrm{pH}$. However, the cell-wall polysaccharides of bran are poorly degraded in man, as is evident from the present study, and so any change in $\mathrm{pH}$ due to the production of short-chain fatty acids in the caecum is lost by the time faecal material is expelled.

\section{Methane results}

The frequency of methane producers $(37 \%)$ was within the limits that one might expect for a group of this composition. The association of slow transit and high $\mathrm{pH}$ found in the methane producers could indicate that this type of colon provides a more suitable environment for the rather slow-growing methano-bacteria. On the other hand, the fact that the overall reaction in a mixed population of bacteria containing methano-bacteria is $\mathrm{C}_{6} \mathrm{H}_{12} \mathrm{O}_{6} \rightarrow 3 \mathrm{CH}_{4}+3 \mathrm{CO}_{2}$ (Klass, 1984) could mean that in the presence of these organisms the residues in the colon are more completely converted to gases with the result that faecal output is low and transit time longer. Since these reactions take place without the formation of organic anions the higher $\mathrm{pH}$ also could be the result rather than the cause of the presence of methano-bacteria.

The authors thank Dr Peter Russell Eggitt, Director of Dalgety-Spillers Research and Technology Centre, Cambridge for encouraging the collaboration that was necessary for this study; Paul Catterall for help in preparing the diets; Dr D. A. T. Southgate for the preliminary analysis of the breads; Dr Rhys Williams for help in taking blood; Ranjit Choolun for technical assistance; and finally the volunteers for their enthusiasm and co-operation.

\section{REFERENCES}

Andersson, H., Nävert, B., Bingham, S. A., Englyst, H. N. \& Cummings, J. H. (1983). British Journal of Nutrition 50, 503-510.

Bingham, S. A., Williams, D. R. R. \& Cummings, J. H. (1985). British Journal of Cancer 52, 399-402.

Branch, W. J. \& Cummings, J. H. (1978), Gut 19, 371-376.

Brittain, G. D., Sullivan, J. E. \& Schewe, L. R. (1971). In Recent Advances in Gas Chromatography, pp. 223-229 [I. Domsky and E. S. Perry, editors]. New York: Marcel Dekker.

Brobst, K. M. \& Lott, C. E. Jr (1966). Cereal Chemistry 43, 35-43.

Burkitt, D. P., Walker, A. R. P. \& Painter, N. S. (1972). Lancet ii, 1408-1412.

Burstein, M., Scholnick, H. R. \& Morfin, R. (1970). Journal of Lipid Research 11, 583-595.

Connell, A. M., Hilton, C., Irvine, G., Lennard-Jones, J. E. \& Misiewicz, J. J. (1965). British Medical Journal ii, 1095-1099.

Cummings, J. H. (1978). Journal of Plant Foods 3, 83-95.

Cummings, J. H. (1982). In Dietary Fiber in Health and Disease, pp. 9-22 [G. V. Vahouny and D. Kritchevsky, editors]. New York: Plenum Press.

Cummings, J. H., Hill, M. J., Jenkins, D. J. A., Pearson, J. R. \& Wiggins, H. S. (1976a). American Journal of Clinical Nutrition 29, 1468-1473.

Cummings, J. H., Hill, M. J., Jivraj, T., Houston, H., Branch, W. J. \& Jenkins, D. J. A. (1979). American Journal of Clinical Nutrition 32, 2086-2093.

Cummings, J. H., Jenkins, D. J. A. \& Wiggins, H. S. (1976b). Gut 17, 210-218.

Cummings, J. H., Southgate, D. A. T., Branch, W., Houston, H., Jenkins, D. J. A. \& James, W. P. T. (1978a). Lancet i, 5-8.

Cummings, J. H., Wiggins, H. S., Jenkins, D. J. A., Houston, H., Jivraj, T., Drasar, B. S. \& Hill, M. J. (1978 b). Journal of Clinical Investigation 61, 953-963. 
Durnin, J. V. G. A. \& Womersley, J. (1974). British Journal of Nutrition 32, 77-97.

Eastwood, M. A., Brydon, W. G. \& Tadesse, K. (1980). In Medical Aspects of Dietary Fiber, pp. 1-26 [G. A. Spiller and R. M. Kay, editors]. New York: Plenum Press.

Englyst. H., Wiggins, H. S. \& Cummings, J. H. (1982). Analyst 107, 307-318.

Gear, J. S. S. (1979). Epidemiological studies of the role of dietary fibre in the aetiology of disease. PhD Thesis, University of Oxford.

Klass, D. L. (1984). Science 223, 1021-1028.

McCance, R. A. \& Walsham, C. M. (1948). British Journal of Nutrition 2, 26-41.

McMichael, A. J. \& Potter, J. D. (1980). Journal of the National Cancer Institute 65, 1201-1207.

McMichael, A. J. \& Potter, J. D. (1982). Lancet i, 1190-1191.

Macrae, T. F., Hutchinson, J. C. D., Irwin, J. O., Bacon, J. S. D. \& McDougall, E. I. (1942). Journal of Hygiene 42, 423-435.

Paul, A. A. \& Southgate, D. A. T. (1978). McCance \& Widdowson's The Composition of Foods. London: H. M. Stationery Office.

Payler, D. K., Pomare, E. W., Heaton, K. W. \& Harvey, R. F. (1975). Gut 16, 209-213.

Roe, J. H. (1955). Journal of Biological Chemistry 212, 335-343.

Roschlau, v. P., Bernt, E. \& Gruber, W. (1974). Zeitschrift für Klinische Chemie: Klinische Biochemie 12, $403-407$.

Royal College of General Practitioners (1979). Morbidity Statistics from General Practice 1971-1972. 2nd National Study. Studies on Medical and Population Subjects no. 36. London: H. M. Stationery Office.

Royal College of Physicians (1980). Medical Aspects of Dietary Fibre. London: Pitman Medical.

Southgate, D. A. T. (1976). In Fiber in Human Nutrition, pp. 73-107 [G. A. Spiller and R. J. Amen, editors]. New York: Plenum Press.

Southgate, D. A. T., Branch, W. J., Hill, M. J., Drasar, B. S., Waiters, R. L., Davies, P. S. \& Baird, 1. M. (1976). Metabolism 25, 1129-1135.

Stephen, A. M. (1980). Dietary fibre and hurnan colonic function. PhD Thesis, University of Cambridge.

Stephen, A. M. \& Cummings, J. H. (1979). Proceedings of the Nutrition Society 38, 141A.

Stephen, A. M. \& Cummings, J. H. (1980). Nature 284, 283-284.

Van Kampen, E. J. \& Zijlstra, W. G. (1961). Clinica Chimica Acta 6, 538-544.

Wahlefeld, A. W. (1974). In Methods of Enzymatic Analysis, 2nd English ed (translated from 3rd German ed), pp. 1831-1839 [H. U. Bergmeyer, editor]. New York and London: Verlag Chemie Weinheim and Academic Press.

Walker, A. R. P., Walker, B. F. \& Segal, I. (1979). South African Medical Journal 55, 495-498.

Wootton, I. D. P. (1974). In Microanalysis in Medical Biochemistry, 5th ed, pp. 218-220. Edinburgh: Churchill Livingstone.

World Health Organization (1973). Energy and Protein Requirements. Report of Joint FAO/WHO Ad Hoc Expert Cornmittee. Technical Report Series no. 522. Geneva: WHO. 